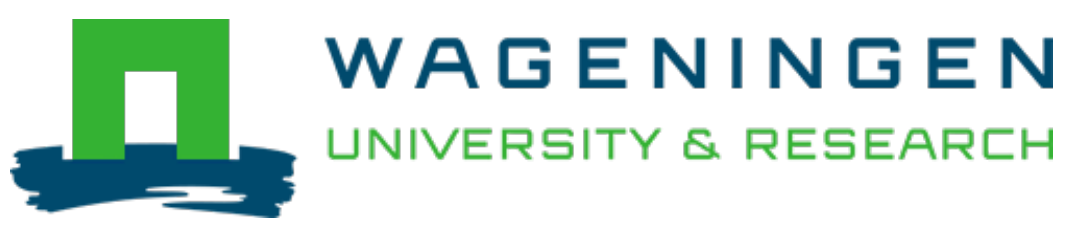

\title{
Border-row proportion determines strength of interspecific interactions and crop yields in maize/peanut strip intercropping
}

\author{
Field Crops Research \\ Wang, Ruonan; Sun, Zhanxiang; Zhang, Lizhen; Yang, Ning; Feng, Liangshan et al \\ https://doi.org/10.1016/j.fcr.2020.107819
}

This article is made publicly available in the institutional repository of Wageningen University and Research, under the terms of article $25 \mathrm{fa}$ of the Dutch Copyright Act, also known as the Amendment Taverne. This has been done with explicit consent by the author.

Article 25 fa states that the author of a short scientific work funded either wholly or partially by Dutch public funds is entitled to make that work publicly available for no consideration following a reasonable period of time after the work was first published, provided that clear reference is made to the source of the first publication of the work.

This publication is distributed under The Association of Universities in the Netherlands (VSNU) 'Article $25 \mathrm{fa}$ implementation' project. In this project research outputs of researchers employed by Dutch Universities that comply with the legal requirements of Article $25 \mathrm{fa}$ of the Dutch Copyright Act are distributed online and free of cost or other barriers in institutional repositories. Research outputs are distributed six months after their first online publication in the original published version and with proper attribution to the source of the original publication.

You are permitted to download and use the publication for personal purposes. All rights remain with the author(s) and / or copyright owner(s) of this work. Any use of the publication or parts of it other than authorised under article $25 \mathrm{fa}$ of the Dutch Copyright act is prohibited. Wageningen University \& Research and the author(s) of this publication shall not be held responsible or liable for any damages resulting from your (re)use of this publication.

For questions regarding the public availability of this article please contact openscience.library@,wur.nl 


\title{
Border-row proportion determines strength of interspecific interactions and crop yields in maize/peanut strip intercropping
}

\author{
Ruonan Wang ${ }^{\mathrm{a}}$, Zhanxiang Sun ${ }^{\mathrm{b}, \mathrm{c}}$, Lizhen Zhang ${ }^{\mathrm{a}, *}$, Ning Yang ${ }^{\mathrm{a}, \mathrm{b}, \mathrm{c}}$, Liangshan Feng ${ }^{\mathrm{b}, \mathrm{c}}$, \\ Wei Bai ${ }^{\mathrm{a}, \mathrm{b}, \mathrm{c}}$, Dongsheng Zhang ${ }^{\mathrm{a}}$, Qi Wang ${ }^{\mathrm{a}}$, Jochem B. Evers ${ }^{\mathrm{d}}$, Yang Liu ${ }^{\mathrm{b}, \mathrm{c}}$, Jianhong Ren ${ }^{\mathrm{a}}$, \\ Yue Zhang ${ }^{\mathrm{a}}$, Wopke van der Werf ${ }^{\mathrm{d}}$ \\ ${ }^{a}$ Agricultural Meteorology Department, College of Resources and Environmental Sciences, China Agricultural University, Beijing, 100193, China \\ ${ }^{\mathrm{b}}$ Tillage and Cultivation Research Institute, Liaoning Academy of Agricultural Sciences, Shenyang, 110161, Liaoning, China \\ ${ }^{\mathrm{c}}$ National Agricultural Experimental Station for Agricultural Environment, Fuxin, 123102, Liaoning, China \\ ${ }^{\mathrm{d}}$ Wageningen University, Centre for Crop Systems Analysis, Droevendaalsesteeg 1, 6708 PB, Wageningen, the Netherlands
}

\section{A R T I C L E I N F O}

\section{Keywords:}

border-row effect

relative yield total

row configuration

strip cropping

yield components

\begin{abstract}
A B S T R A C T
Strip intercropping enables increases in yields and ecological services in agriculture. Crop yields of species grown in strip intercropping are often related to the yield responses (increases or decreases) in the outer rows of the strips: the border rows. This suggests that the yield response can be modulated by changing the proportion of border rows in the field. Here we studied the relationship between component species yields and proportion of border rows in strip intercrops of maize (Zea mays L.) and peanut (Arachis hypogaea Linn.). We tested four different intercrops with equal proportions of maize and peanut but a different number of rows per strip: M2P2 (2 rows maize intercropped with 2 rows peanut), M4P4, M6P6, M8P8, and sole maize (SM) and sole peanut (SP). The border-row proportions were $1,0.5,0.33$ and 0.25 for the intercropping M2P2 to M8P8, respectively, and 0 for the pure stands. Yield responded positively to the proportion of border rows for maize, but negatively for peanut, confirming the dominance of maize in this system. Kernel number per ear of maize and pod number per plant of peanut were the main yield components that responded to the border-row proportion. Across three years, relative maize yield (yield in intercropping divided by yield in monoculture), varied from 0.76 in M2P2 to 0.56 in M8P8, while relative peanut yield varied from 0.19 in M2P2 to 0.39 in M8P8. Relative yield total was not significantly different from one in any of the mixtures. Yield of intercropped maize in border rows was $48 \%$ higher than in inner rows and the sole crop, in part due to a significantly higher kernel number per ear (13\%). Yield of intercropped peanut in border rows was on average $29 \%$ lower than in inner rows and $48 \%$ lower than in sole peanut. Yield responses in border rows were independent from the border-row proportion. The results show that relative crop yields responded strongly to variation in border-row proportion resulting from variation in strip width from 1 to $4 \mathrm{~m}$. Strip width thus provides a mechanism to control the strength of interspecific plant interactions and relative yields in strip intercropping.
\end{abstract}

\section{Introduction}

Intercropping is the cultivation of multiple crop species in one field for the whole or part of their growing period (Vandermeer, 1989). Yields are often higher and more stable in intercropping than in monocultures (Mead and Willey, 1980; Lithourgidis et al., 2011; Yu et al., 2015; Raseduzzaman and Jensen, 2017). Intercropping may also improve soil quality and soil carbon sequestration (Cong et al., 2015) and reduce soil wind erosion (Chen et al., 2010). Furthermore, intercropping can reduce plant diseases (Trenbath, 1993; Boudreau, 2013;
Zhang et al., 2019).

In intercropping, species are mixed at a fine spatial resolution, allowing strong interactions between species such that benefits of interactions between neighbouring allo-specific plants, e.g. facilitation of nutrient uptake, are maximized (Li et al., 2013). However, intercrops with narrow strips are difficult to manage with modern machinery, which requires operating widths of $3 \mathrm{~m}$ or more. Intercrops with wider strips would be easier to manage with existing equipment, but interspecific interactions are predicted to be reduced when strips are wide (van Oort et al., 2020). Using wide strips has been promoted to combat

\footnotetext{
* Corresponding author.

E-mail addresses: wangruonan@cau.edu.cn (R. Wang), zhanglizhen@cau.edu.cn (L. Zhang).
} 
soil erosion and to limit plant diseases (Bravo and Silenzi, 2002; Ma et al., 2007). Some studies have claimed yield benefits of wide strips, but the mechanistic basis of such advantages have not been elucidated (Francis et al., 1986).

Yield increase in intercropping depends on complementary uptake of resources, i.e. a reduction of competition, and more efficient resource uptake due to spatial and temporal differences between species in resource demand (Zhang et al., 2007; Li et al., 2013). Complementarity may exist both for aboveground and belowground resources (light, water and nutrients) (Morris and Garrity, 1993; Li et al., 1999). The strongest interactions in strip intercrops occur between plants in neighbouring rows, due to direct interaction between individuals of species in terms of capture of radiation, water and nutrients, and the release of exudates in the rhizosphere soil that can mobilize nutrients and result in facilitation (Li et al., 2013; Zhang and Li, 2003).

However, shading effects of taller species may extend over multiple rows of a subordinate companion species (Liu et al., 2017; Wang et al., 2016). It is therefore expected that the effects of mixing species will diminish as species strips are widened, and ultimately vanish when strips are very wide and border-row proportion converges to zero (van Oort et al., 2020). Thus, the transition from narrow to wide strips that can be mechanized is expected to lead to loss of both beneficial and detrimental interspecific interactions.

Few studies have analysed the relationship between border-row proportion and crop performance in intercrops. Zhang et al. (2007) studied the effect of different row configuration in wheat/cotton relay strip intercropping, and found higher wheat yields in 3:1 intercropping (wheat:cotton) than in 6:2 intercropping in which the ratio of species densities was equal, but the strip width in the 6:2 system was twice as large as that in the 3:1 system. There is a shortage of systematic studies on the effects of a gradual increase of the strip width (measured in terms of the number of rows per strip) on crop performance.

Here, we assess the effect of strip width and the resulting proportion of border rows on the interaction between maize and peanut. We designed a three-year field experiment with border-row proportions ranging from 0 (sole crops) to 1 (strips with 2 rows which are both border rows). The objectives of this study were (a) to quantify the effect of border-row proportion on species performance; and (b) to determine the opportunities to enhance crop yields in maize/peanut intercropping by modifying border-row proportion through the manipulation of strip width.

\section{Materials and methods}

\subsection{Experimental site}

The field experiments were carried out at the Scientific Observation and Experiment Station in Fuxin $\left(42.11^{\circ} \mathrm{N}, 121.65^{\circ} \mathrm{E}\right)$, Liaoning, China from 2015 to 2017. Fuxin is located in the south Khorchin area in Northeast China. The area has a fragile agricultural ecosystem with rainfed agriculture. Soil texture is sandy soil with a bulk density of 1.42 $\mathrm{g} \mathrm{cm}^{-3}, 14.4 \mathrm{~g} \mathrm{~kg}^{-1}$ of soil organic matter, $0.78 \mathrm{~g} \mathrm{~kg}^{-1}$ of total $\mathrm{N}, 17.4 \mathrm{mg}$ $\mathrm{kg}^{-1}$ of available $\mathrm{P}$ and $69.5 \mathrm{mg} \mathrm{kg}^{-1}$ of available $\mathrm{K}$ in the top $20 \mathrm{~cm}$ of the soil profile. Climate is cold with a dry winter and hot summer, characterized as Dwa in the updated Köppen-Geiger climate classification (Peel et al., 2007). Total rainfall during the growing season (May to September) was $247 \mathrm{~mm}$ in 2015, $492 \mathrm{~mm}$ in 2016 and $351 \mathrm{~mm}$ in 2017, i.e. with large variability between and within years (Table 1).

\subsection{Experimental design}

Each experiment was laid out as a randomized complete block design with three replicates. Treatments were four intercropping configurations, containing 2, 4, 6 or 8 rows of maize with a matching number of peanut rows (M2P2 to M8P8), and two pure stands acting as reference: sole maize (SM) and sole peanut (SP). Row spacing was $50 \mathrm{~cm}$ in all the treatments. Maize and peanut had a $50 \%$ land proportion in each of the intercrop treatments (Figs. 1 and 2). Plant density of sole maize and within the maize strip in intercrops was 6 plants $\mathrm{m}^{-2}$, and plant density of sole peanut and within the peanut strip in intercrops was 12 plants $\mathrm{m}^{-2}$. Due to the $50 \%$ land use proportion, the overall plant density was 3 plants per $\mathrm{m}^{2}$ total intercrop area for intercropped maize, and 6 plants $\mathrm{m}^{-2}$ total intercrop area for intercropped peanut, i.e. half of the density in the strip (Fig. 2). Each intercrop plot had three identical strips for each component crop, resulting in plot areas of 42, 84, 126 and $168 \mathrm{~m}^{2}$ for M2P2, M4P4, M6P6 and M8P8, respectively. SM and SP had $63 \mathrm{~m}^{2}$ plots.

In order to quantify the border-row effect, plant rows were numbered from the border rows at both sides of a species strip to the middle. Row 1 was the border row in all the intercropping treatments and other rows (rows 2 to 4 , depending on the design) were inner rows. Borderrow proportion (BRP) is defined as the ratio of border rows over total rows in intercropping for each component crop. The BRP was $1,0.5$, 0.33, 0.25 for M2P2, M4P4, M6P6, M8P8, respectively, and the BRP for pure stands was 0 (Table 2). All samples and measurements were made at least $1 \mathrm{~m}$ away from the plot edge to avoid edge effects. The term "border row" in this study thus refers to the border row of a strip in intercropping, not to the edges of a plot.

Maize and peanut were sown on $4^{\text {th }}$ May in $2015,22^{\text {nd }}$ May in 2016 and $20^{\text {th }}$ May in 2017 and harvested on $1^{\text {st }}$ October when crops were physiological matured in all three years. Maize variety was the locally common cultivar Zhengdan 958 and the peanut variety was Baisha 1016. Only basal fertilizer was applied, including $112 \mathrm{~kg} \mathrm{ha}^{-1} \mathrm{~N}, 112 \mathrm{~kg}$ ha $^{-1} \mathrm{P}_{2} \mathrm{O}_{5}$ and $112 \mathrm{~kg} \mathrm{ha}^{-1} \mathrm{~K}_{2} \mathrm{O}$.

\subsection{Measurements}

\subsubsection{Yield and yield components}

Yield samples were taken on $1^{\text {st }}$ October in all 3 years. The sampling area for final yield of maize and peanut in intercropping comprised an entire intercropping strip (two species) over $5 \mathrm{~m}$ row length in each plot, for a total area per plot of $10,20,30$ and $40 \mathrm{~m}^{2}$ for M2P2, M4P4, M6P6 and M8P8, respectively. Yield was measured per row. The sampling area for both sole maize and sole peanut was $5 \mathrm{~m}^{2}(5 \mathrm{~m}$ in length and $1 \mathrm{~m}$ in width). For maize, ears were counted and weighted. Ten ears were randomly selected to quantify kernel number per ear and 1000kernel weight. For peanut, pod number per plant, seed number per pod and 1000-seed weight were measured for all plants in sampling area. The grains were sun-dried to a water content of approximately $14 \%$. Crop yield was expressed per unit of total intercrop area. Therefore, if an intercropping treatment would have no effect on plant performance, yield in the intercrop would be expected to be $50 \%$ of that in the sole crop, given the land use proportion of $50 \%$ of both species in the intercrops.

\subsubsection{Dry matter and harvest index}

The aboveground dry matter of maize and peanut in all treatments was measured on $25^{\text {th }}$ September in 2015 and $27^{\text {th }}$ September in 2016 and 2017. Three plants in a $4 \mathrm{~m}^{2}$ sub-sampling area in each plot were randomly selected to determine crop final dry matter. After measuring fresh weight, the samples were oven-dried at $100{ }^{\circ} \mathrm{C}$ for 1 hour to deactivate enzymes and then at $85{ }^{\circ} \mathrm{C}$ for 48 hours to a constant weight. The harvest index (HI) was then calculated as grain yield divided by final dry matter for each plot.

\subsection{Data analysis}

\subsubsection{Relative yield total at system level}

Relative yield total (RYT) is calculated in the same way as land equivalent ratio (Mead and Willey, 1980; Yu et al., 2016), and equals the sum of relative yields (RY, yield in intercropping over yield in pure stand) of maize and peanut. 
Table 1

Weather data during crop growing seasons in 2015-2017 in Fuxin, Liaoning, China.

\begin{tabular}{|c|c|c|c|c|c|c|c|c|c|}
\hline \multirow[t]{2}{*}{ Month } & \multicolumn{3}{|c|}{ Mean air temperature $\left({ }^{\circ} \mathrm{C}\right)$} & \multicolumn{3}{|c|}{ Total rainfall (mm) } & \multicolumn{3}{|c|}{ Total sunshine hour (h) } \\
\hline & 2015 & 2016 & 2017 & 2015 & 2016 & 2017 & 2015 & 2016 & 2017 \\
\hline May & 17.6 & 18.6 & 18.8 & 49.5 & 109 & 21.8 & 251 & 278 & 301 \\
\hline June & 21.7 & 23.0 & 23.3 & 118 & 56.2 & 50.1 & 226 & 252 & 271 \\
\hline July & 24.5 & 25.4 & 26.8 & 35.7 & 204 & 52.3 & 250 & 216 & 264 \\
\hline August & 23.8 & 23.9 & 23.0 & 33.4 & 101 & 187 & 249 & 274 & 188 \\
\hline September & 18.4 & 18.4 & 18.0 & 10.1 & 21.7 & 39.7 & 245 & 228 & 241 \\
\hline Total $^{\mathrm{a}}$ & 21.2 & 21.8 & 22.0 & 247 & 492 & 351 & 1220 & 1248 & 1265 \\
\hline
\end{tabular}

a The air temperature is averaged daily mean from May 1 to September 30 . The rainfall and sunshine hour are total values from May 1 to September 30 .
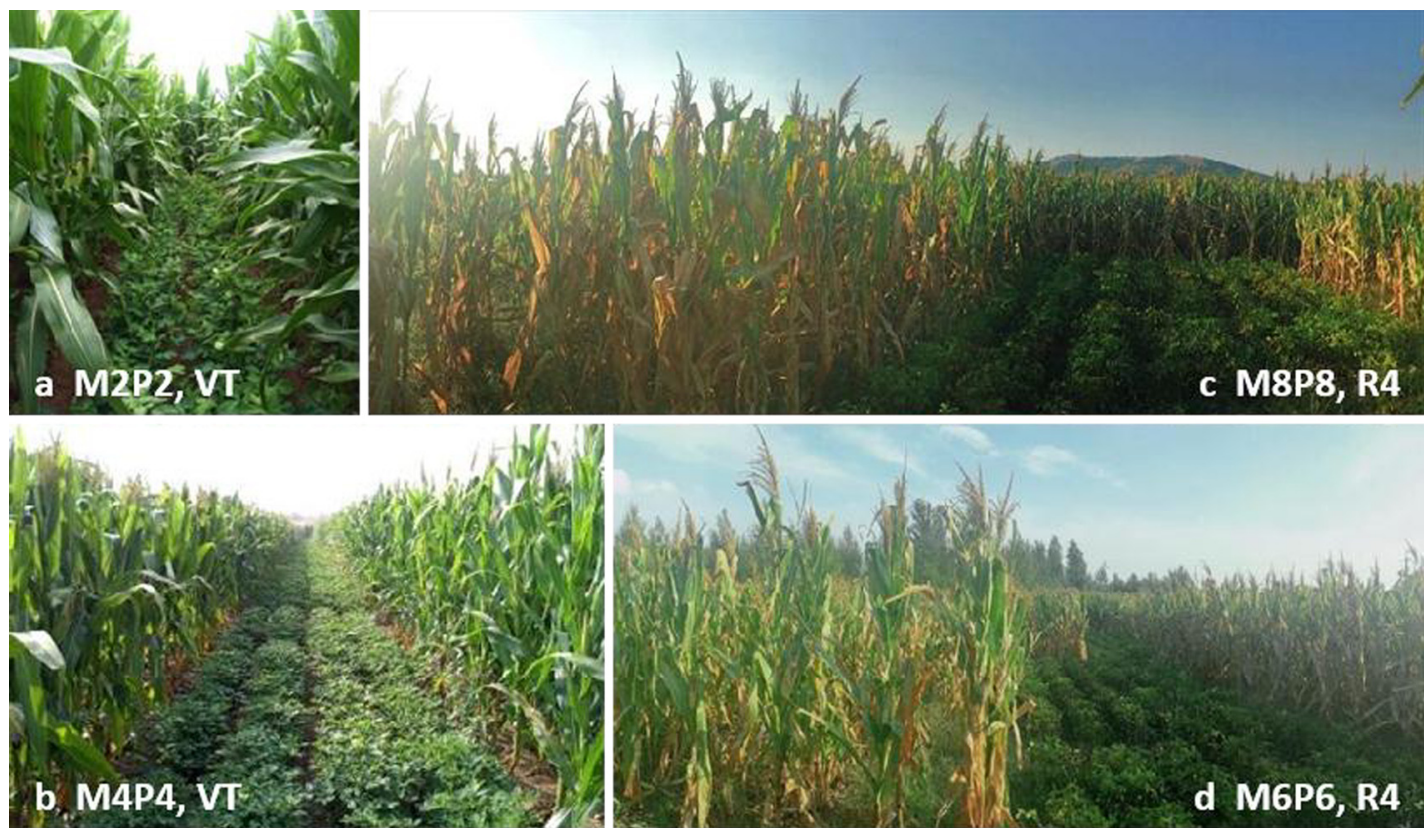

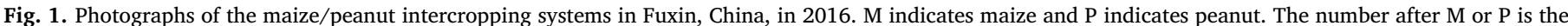
number of rows per strip in the intercrop. VT indicates maize tasseling stage and R4 indicates maize dough stage.

$R Y T=R Y_{\mathrm{m}}+R Y_{\mathrm{p}}=\frac{Y_{\text {inter } \mathrm{m}}}{Y_{\text {sole, } \mathrm{m}}}+\frac{Y_{\text {inter }, \mathrm{p}}}{Y_{\text {sole }, \mathrm{p}}}$

where $R Y T$ is relative yield total of an intercrop. $R Y_{\mathrm{m}}$ is the relative yield of maize and $R Y_{\mathrm{p}}$ is the relative yield of peanut. $Y_{\text {inter,m }}$ and $Y_{\text {inter,p }}$ are yields ( $\mathrm{g}$ per $\mathrm{m}^{2}$ of intercrop area) of maize and peanut in intercropping. $Y_{\text {sole, } \mathrm{m}}$ and $Y_{\text {sole,p }}$ are yields $\left(\mathrm{g} \mathrm{m}^{-2}\right)$ of maize and peanut in the pure stands. When RYT is greater than 1 , the intercropping system uses land more efficiently than monocultures (Willey and Rao, 1980).

\subsubsection{Yield at plant level in response to border-row proportion}

Exponential regressions were used to quantify the plant yield response to BRP in maize and peanut. For maize, the dominant crop, the fitted equation is an increasing negative exponential that converges to a maximum value at high BRP (Eq. 2). For peanut, the dominated crop, the fitted relationship is a declining negative exponential that converges to a minimum value at high BRP (Eq. 3).

Maize: $Y_{1}=\left(a_{1}-b_{1}\right) \cdot\left(1-e^{-k_{1} \cdot B R P}\right)+b_{1}$

Peanut: $Y_{2}=\left(a_{2}-b_{2}\right) \cdot\left(e^{-k_{2} \cdot B R P}\right)+b_{2}$

where $Y_{1}$ or $Y_{2}$ indicate the yield per plant $\left(\mathrm{g}\right.$ plant $\left.^{-1}\right)$ of maize or peanut, averaged over the whole intercrop plot. $B R P$ is the border-row proportion. In both equations, $a$ represents the maximum yield for a species, while $b$ represents the minimum yield. Parameter $k$ (dimensionless) is a coefficient representing the sensitivity of yield to BRP. Scaling up to system, the crop yield at field level equals plant yield of maize or peanut $\left(Y_{1}\right.$ or $\left.Y_{2}\right)$ multiplied with the overall plant density across the whole intercrop area.

\subsubsection{Statistical analysis}

Root mean square error (RMSE) and normalized root mean square error (nRMSE) were used to assess the fitted relationships:

$R M S E=\sqrt{\frac{1}{n} \sum_{i=1}^{n}\left(S_{i}-O_{i}\right)^{2}}$

$n R M S E=\frac{R M S E}{O_{\text {mean }}} \times 100 \%$

where $S_{i}$ is the fitted value using the model, $O_{i}$ is the observed data from field experiment, $n$ is the number of samples and $O_{\text {mean }}$ is the mean of all observations. We also determined $R^{2}$.

Analysis of variance (ANOVA) was used to assess treatment effects on yield, dry matter and harvest index, and year effect on fitted parameters using SPSS 20 (IBM, USA). Least significant differences (LSD) were used to separate treatment differences in means at 0.05 level.

\section{Results}

\subsection{Yields at system level}

The yield of maize in M2P2 across three years was $659 \mathrm{~g} \mathrm{~m}^{-2}$ measured over the whole intercrop area, and significantly higher than 

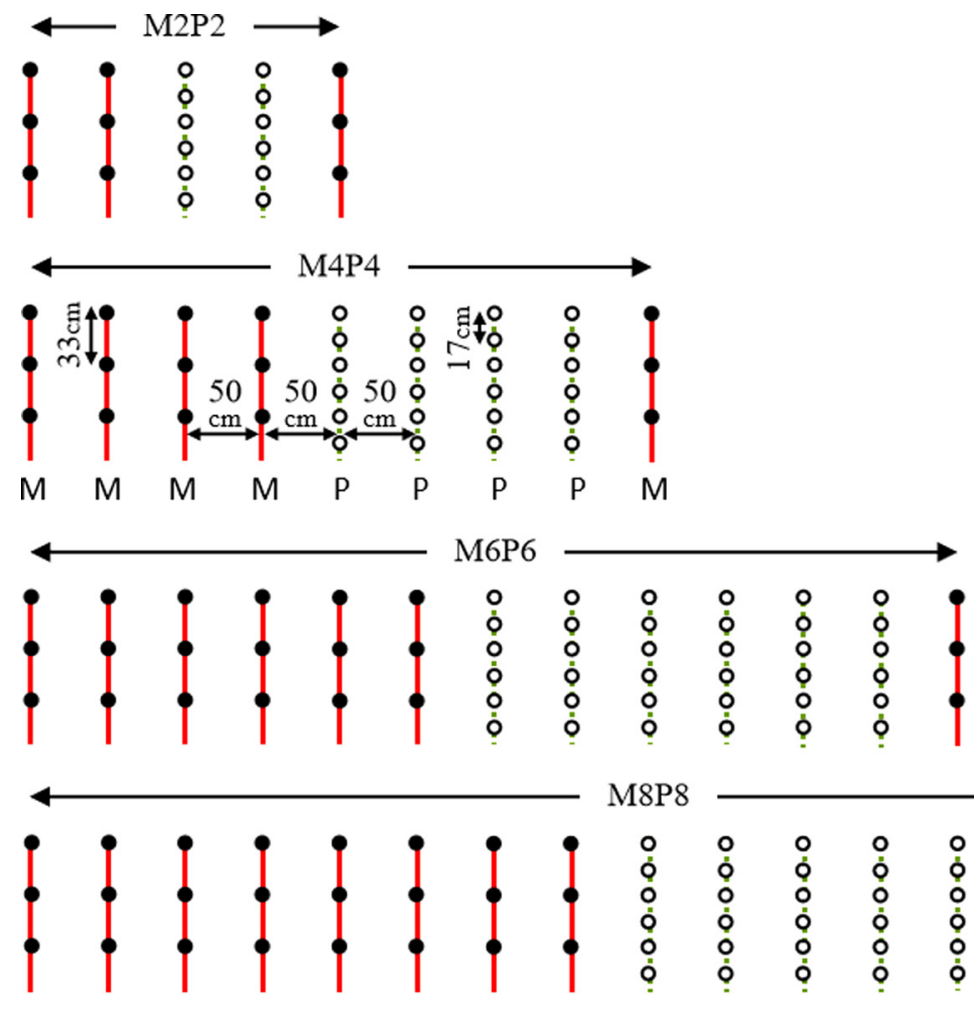

\section{M8P8}

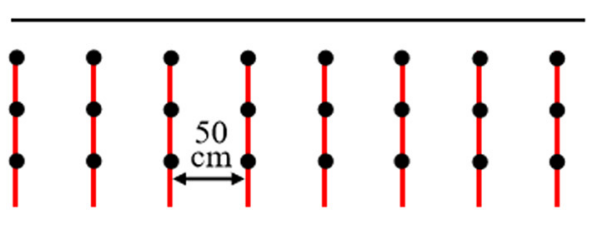

$\mathrm{SM}$

\begin{tabular}{|c|c|c|c|c|c|}
\hline $\begin{array}{ll}0 & 0 \\
0 & 0 \\
0 & 0 \\
0 & 0 \\
0 & 0 \\
0 & 0 \\
0 & 0 \\
0 & 0\end{array}$ & $\begin{array}{l}0 \\
0 \\
o \\
o \\
0 \\
0 \\
0\end{array}$ & $\begin{array}{l}0 \\
0 \\
0 \\
o \\
0 \\
0 \\
0\end{array}$ & $\begin{array}{l}0 \\
0 \\
0 \\
0 \\
0 \\
0 \\
0\end{array}$ & $\begin{array}{l}0 \\
o \\
o \\
o \\
0 \\
0 \\
0\end{array}$ & $\begin{array}{l}0 \\
0 \\
0 \\
0 \\
0 \\
0 \\
0\end{array}$ \\
\hline
\end{tabular}

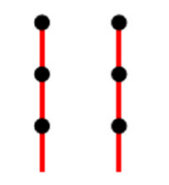

\begin{tabular}{|c|c|c|c|c|c|c|}
\hline $\begin{array}{l}0 \\
\text { ó } \\
0 \\
o ̂ \\
0 \\
0 \\
0\end{array}$ & $\begin{array}{l}\text { o } \\
\text { ọ } \\
\text { o } \\
\text { ọ } \\
\text { o } \\
\text { o }\end{array}$ & $\begin{array}{l}\text { o } \\
\text { ó } \\
\text { ó } \\
\text { ó } \\
\text { ò } \\
\text { ó }\end{array}$ & $\begin{array}{l}\text { o } \\
\text { og } \\
\text { ô } \\
\text { ò } \\
\text { o } \\
\text { ó }\end{array}$ & $\begin{array}{l}0 \\
o b \\
o \\
\text { ó } \\
\text { o̊ } \\
\text { ó }\end{array}$ & $\begin{array}{l}\text { o } \\
\text { ó } \\
\text { o } \\
\text { ó } \\
\text { o } \\
\text { ô }\end{array}$ & $\begin{array}{l}0 \\
o b \\
o \\
o ́ \\
o ́ \\
0 \\
0\end{array}$ \\
\hline
\end{tabular}

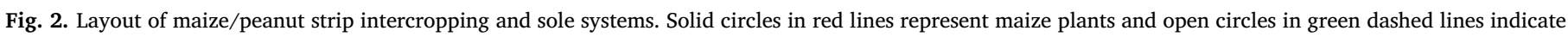
peanut plants. Row distance was $50 \mathrm{~cm}$ in all treatments, while plant distance within a species was the same across all treatments.

Table 2

Row configurations of maize/peanut intercropping and pure stands in the experiment.

\begin{tabular}{llllll}
\hline Treatment & $\begin{array}{l}\text { Number of rows in a strip of maize } \\
\text { or peanut }^{\mathrm{a}}\end{array}$ & $\begin{array}{l}\text { Land proportion } \\
\text { of maize or } \\
\text { peanut }\end{array}$ & $\begin{array}{l}\text { Border-row } \\
\text { proportion }\end{array}$ \\
\cline { 2 - 4 } & $\begin{array}{l}\text { Border }^{\mathrm{r}} \text { rows }^{\mathrm{b}} \\
\text { rows }\end{array}$ & $\begin{array}{l}\text { Inner } \\
\text { rows }\end{array}$ & $\begin{array}{l}\text { Total } \\
\text { number of } \\
\text { rows }\end{array}$ & & \\
\hline M2P2 & 2 & 0 & 2 & 0.5 & 1.00 \\
M4P4 & 2 & 2 & 4 & 0.5 & 0.50 \\
M6P6 & 2 & 4 & 6 & 0.5 & 0.33 \\
M8P8 & 2 & 6 & 8 & 0.5 & 0.25 \\
SM & 0 & 16 & 16 & 1.0 & 0.00 \\
SP & 0 & 16 & 16 & 1.0 & 0.00 \\
\hline
\end{tabular}

$\mathrm{M}$ indicates maize and $\mathrm{P}$ indicates peanut. The number after $\mathrm{M}$ and $\mathrm{P}$ is the number of rows in a strip.

${ }^{\text {a }}$ Nmuber of rows in intercropping is for a strip while it is the number of rows per plot in sole crops.

$\mathrm{b}$ Border row indicates the first row from the borderline of a strip and other rows are inner rows.

c Border-row proportion is the number of border rows over the total number of rows of a component crop in a strip in the intercrop. in M6P6 (28\%) and M8P8 (33\%). Compared to an expected yield of $50 \%$ of the sole maize yield (due to the $50 \%$ land use proportion) the maize yield in M2P2, M4P4, M6P6 and M8P8 was 51\%, 34\%, 18\% and $11 \%$ higher than expected (Table 3 ). Average across the three years, the yield of peanut in M8P8 $\left(98.4 \mathrm{~g} \mathrm{~m}^{-2}\right)$ was significantly higher than in M4P4 (30\%) and M2P2 (99\%). Maximum yield of peanut in M8P8 was $24 \%$ lower than in sole peanut, while the lowest yield in M2P2 was $62 \%$ lower than in sole control. Peanut yield differed significantly between years $(\mathrm{P}<0.01)$.

Aboveground dry matter in both maize and peanut did not significantly differ between intercropping patterns. Both maize and peanut dry matter were significantly $(P<0.05)$ affected by year (weather-related). Harvest index (HI) was significantly different between treatments $(\mathrm{P}<0.05)$ in both maize and peanut. $\mathrm{HI}$ of intercropped maize was significantly higher than in the pure stand, especially in M2P2 intercropping. In peanut, the HI was significantly lower $(44.2 \%)$ in M2P2 than in the sole crop. The HI of intercropped peanut in M2P2 and M4P4 was lower than in M6P6 and M8P8.

\subsection{Yield components}

Ear number per plant of maize increased with BRP $\left(R^{2}=0.903\right)$ in 
Table 3

Yield, dry matter and harvest index of maize and peanut in the intercrops and sole crops in 2015-2017.

\begin{tabular}{|c|c|c|c|c|c|c|c|}
\hline \multirow[t]{2}{*}{ Year } & \multirow[t]{2}{*}{ Treatment } & \multicolumn{2}{|c|}{ Yield $\left(\mathrm{g} \mathrm{m}^{-2}\right)$} & \multicolumn{2}{|c|}{ Dry matter $\left(\mathrm{g} \mathrm{m}^{-2}\right)$} & \multicolumn{2}{|c|}{ Harvest index } \\
\hline & & Maize & Peanut & Maize & Peanut & Maize & Peanut \\
\hline \multirow[t]{7}{*}{2015} & M2P2 & $607 \mathrm{~b}$ & $64.9 \mathrm{~d}$ & $1027 \mathrm{~b}$ & $186 \mathrm{~b}$ & $0.59 \mathrm{a}$ & $0.35 \mathrm{c}$ \\
\hline & M4P4 & $587 \mathrm{~b}$ & $82.8 \mathrm{~cd}$ & 998 b & $165 \mathrm{~b}$ & $0.59 \mathrm{a}$ & $0.50 \mathrm{~b}$ \\
\hline & M6P6 & $503 \mathrm{~b}$ & $101.8 \mathrm{bc}$ & $807 \mathrm{~b}$ & $228 \mathrm{~b}$ & $0.63 \mathrm{a}$ & $0.45 \mathrm{bc}$ \\
\hline & M8P8 & $459 \mathrm{~b}$ & $120.0 \mathrm{~b}$ & $821 \mathrm{~b}$ & $186 \mathrm{~b}$ & $0.56 \mathrm{a}$ & $0.65 \mathrm{a}$ \\
\hline & Sole maize & $830 \mathrm{a}$ & - & 1652 a & - & $0.51 \mathrm{a}$ & - \\
\hline & Sole peanut & - & $261.0 \mathrm{a}$ & - & 536 a & - & $0.49 \mathrm{~b}$ \\
\hline & SE & 38.3 & 19.2 & 98.4 & 30.8 & 0.22 & 0.12 \\
\hline \multirow[t]{7}{*}{2016} & M2P2 & 717 b & $34.1 \mathrm{c}$ & $1395 \mathrm{~b}$ & $215 \mathrm{~b}$ & $0.52 \mathrm{a}$ & $0.16 \mathrm{~b}$ \\
\hline & M4P4 & $646 \mathrm{bc}$ & $89.2 \mathrm{~b}$ & $1347 \mathrm{~b}$ & $279 \mathrm{~b}$ & $0.48 \mathrm{a}$ & $0.32 \mathrm{a}$ \\
\hline & M6P6 & $524 \mathrm{c}$ & $86.5 \mathrm{~b}$ & $1138 \mathrm{~b}$ & $271 \mathrm{~b}$ & $0.47 \mathrm{a}$ & $0.32 \mathrm{a}$ \\
\hline & M8P8 & $533 \mathrm{c}$ & $96.7 \mathrm{~b}$ & $1186 \mathrm{~b}$ & $300 \mathrm{~b}$ & $0.45 \mathrm{a}$ & $0.32 \mathrm{a}$ \\
\hline & Sole maize & 994 a & - & 2192 a & - & $0.47 \mathrm{a}$ & - \\
\hline & Sole peanut & - & $265.6 \mathrm{a}$ & - & 796 a & - & $0.35 \mathrm{a}$ \\
\hline & SE & 49.5 & 21.4 & 163 & 89.9 & 0.08 & 0.09 \\
\hline \multirow[t]{7}{*}{2017} & M2P2 & $652 \mathrm{~b}$ & $49.6 \mathrm{~b}$ & $1302 \mathrm{~b}$ & $241 \mathrm{~b}$ & $0.54 \mathrm{a}$ & $0.21 \mathrm{c}$ \\
\hline & M4P4 & $521 \mathrm{c}$ & $55.0 \mathrm{~b}$ & $1360 \mathrm{~b}$ & $190 \mathrm{~b}$ & $0.38 \mathrm{a}$ & $0.29 \mathrm{bc}$ \\
\hline & M6P6 & $515 \mathrm{c}$ & $68.7 \mathrm{~b}$ & $1097 \mathrm{~b}$ & $128 \mathrm{~b}$ & $0.47 \mathrm{a}$ & $0.56 \mathrm{a}$ \\
\hline & M8P8 & $469 c$ & $78.3 \mathrm{~b}$ & $1043 \mathrm{~b}$ & $150 \mathrm{~b}$ & $0.45 \mathrm{a}$ & $0.52 \mathrm{a}$ \\
\hline & Sole maize & 799 a & - & 2418 a & - & $0.36 \mathrm{a}$ & - \\
\hline & Sole peanut & - & $245.3 \mathrm{a}$ & - & $578 \mathrm{a}$ & - & $0.44 \mathrm{ab}$ \\
\hline & SE & 35.4 & 20.0 & 355 & 54.5 & 0.08 & 0.09 \\
\hline \multirow[t]{7}{*}{ Average } & M2P2 & $659 \mathrm{~b}$ & $49.5 \mathrm{~d}$ & $1241 \mathrm{~b}$ & $214 \mathrm{~b}$ & $0.55 \mathrm{a}$ & $0.24 \mathrm{c}$ \\
\hline & M4P4 & $585 \mathrm{bc}$ & $75.7 \mathrm{c}$ & $1235 \mathrm{~b}$ & $211 \mathrm{~b}$ & $0.48 \mathrm{ab}$ & $0.37 \mathrm{~b}$ \\
\hline & M6P6 & $514 \mathrm{~cd}$ & $85.7 \mathrm{bc}$ & $1014 \mathrm{~b}$ & $209 \mathrm{~b}$ & $0.52 \mathrm{abc}$ & $0.44 \mathrm{ab}$ \\
\hline & M8P8 & $487 \mathrm{~d}$ & $98.4 \mathrm{~b}$ & $1016 \mathrm{~b}$ & $212 \mathrm{~b}$ & $0.49 \mathrm{bc}$ & $0.50 \mathrm{a}$ \\
\hline & Sole maize & 874 a & - & 2087 a & - & $0.45 \mathrm{c}$ & - \\
\hline & Sole peanut & - & $257.3 \mathrm{a}$ & - & $637 \mathrm{a}$ & - & $0.43 \mathrm{ab}$ \\
\hline & SE & 38.4 & 19.9 & 123 & 55.8 & 0.03 & 0.05 \\
\hline \multirow[t]{3}{*}{$P$} & Treatment & 0.000 & 0.000 & 0.000 & 0.000 & 0.034 & 0.000 \\
\hline & Year & 0.135 & 0.003 & 0.016 & 0.007 & 0.102 & 0.006 \\
\hline & Treatment $\times$ Year & 0.394 & 0.276 & 0.905 & 0.001 & 0.867 & 0.037 \\
\hline
\end{tabular}

Same small letter indicates no significant difference between treatments within same year at $a=0.05$.

2016 from approximately 1.1 in the sole crop (BRP $=0$ ) to 1.6 in the M2P2 intercrop $(B R P=1$ ) (Fig. 3a), but the ear number per plant was consistently around 1 in the other two years at all BRPs. In 2016, with a higher ear number per plant than in the other years, kernel number per ear was significantly lower than in the other years. In all years, the number of kernels per ear increased with BRP (Fig. 3b). There were no significant differences in 1000-kernel weight between treatments (Fig. 3c).

In peanut, pod number per plant decreased substantially with BRP, from approximately 12 pods per plant in the sole crop $(B R P=0)$ to between 6 and 8 pods per plant in the M2P2 system $(B R P=1)$ (Fig. 3d). Seed number per pod did not respond to BRP in 2017, decreased slightly with BRP in 2015, and declined strongly with BRP in 2016 (Fig. 3e). In 2016, intercropped maize had high aboveground dry matter in $\mathrm{M} 2 \mathrm{P} 2(\mathrm{BRP}=1)$ (Table 3$)$ resulting in a strong effect on seed number per pod in peanut, $32 \%$ lower than in the pure peanut stand. Seed weight did not show a clear response to BRP in peanut but there were significant differences between the years (Fig. 3f).

\subsection{Relative yields}

Relative maize yields $\left(R Y_{m}\right)$ in intercropping increased with BRP, from 0.56 in M8P8 (BRP $=0.25)$ to 0.76 in M2P2 $(B R P=1)$ and were all higher than the land use proportion of 0.5 (Fig. 4 a) while there was no significant year effect. Relative yield of intercropped peanut decreased with BRP, ranging from 0.39 in M8P8 (BRP $=0.25$ ) to 0.19 in M2P2 (BRP $=1)$. RY of intercropped peanut was higher in the driest year, 2015, than in the other two years (Fig. 4b). The relative yield total (RYT) of all intercrops ranged from 0.92 (in M6P6) to 0.97 (in M4P4) across the three years, showing no significant difference. In 2015, the RYT was higher than in the other years $(1.02 \pm 0.03)$ but with no significant yield advantage (Fig. 4c).

\subsection{Plant yields in response to border-row proportion}

Plant yield of maize in both intercrops and pure stands fitted well (nRMSE $<6 \%$ and $R^{2}>0.80$ ) a saturating negative exponential relationship with BRP while plant yield of peanut fitted well a declining negative exponential relationship (nRMSE $<14 \%$ and $R^{2}>0.88$ ). Maize responses were similar in 2015 and $2017\left(\mathrm{y}=91.0\left(1-\mathrm{e}^{-1.98 \mathrm{x}}\right)+\right.$ $127, R^{2}=0.949$ ), but larger yields per plant were observed in 2016 , resulting in significantly different parameters for the fitted equation (Fig. 5a; Table 4). Peanut responses were similar in 2015 and 2016 (y = $18.9 \mathrm{e}^{-1.56 \mathrm{x}}+4.02, \mathrm{R}^{2}=0.891$ ), but lower plant yields were observed in 2017, resulting in a significantly different value of $k$ in the fitted equation (Fig. 5b; Table 4). The minimum plant yield $b$ (the yield at no border rows, i.e. pure stands) of maize was higher in 2016 than in the other years. The maximum plant yield $a$ (the yield at highest borderrow proportion, i.e. M2P2) and the coefficient $k$ did not differ significantly between years. For peanut, the coefficient $k$ was significantly higher in 2017 than in other years. Thus, the effect of climate on the yield response to BRP differed between maize and peanut in the intercropping.

\subsection{Border-row effect}

The plant yield of maize was across all years and intercrops $52 \%$ higher in border rows than in sole maize (Fig. 6d). The yields in the inner intercropping rows showed no significant difference, and did not differ with the pure stand. Peanut plant yield was reduced in intercrops in comparison to pure stands, except in rows 3 and 4 in M8P8 in 2015 (Fig. 6e). Across all years and intercrop treatments, the yield of intercropped peanut in border rows was $48 \%$ lower than in sole peanut (Fig. 6h). 

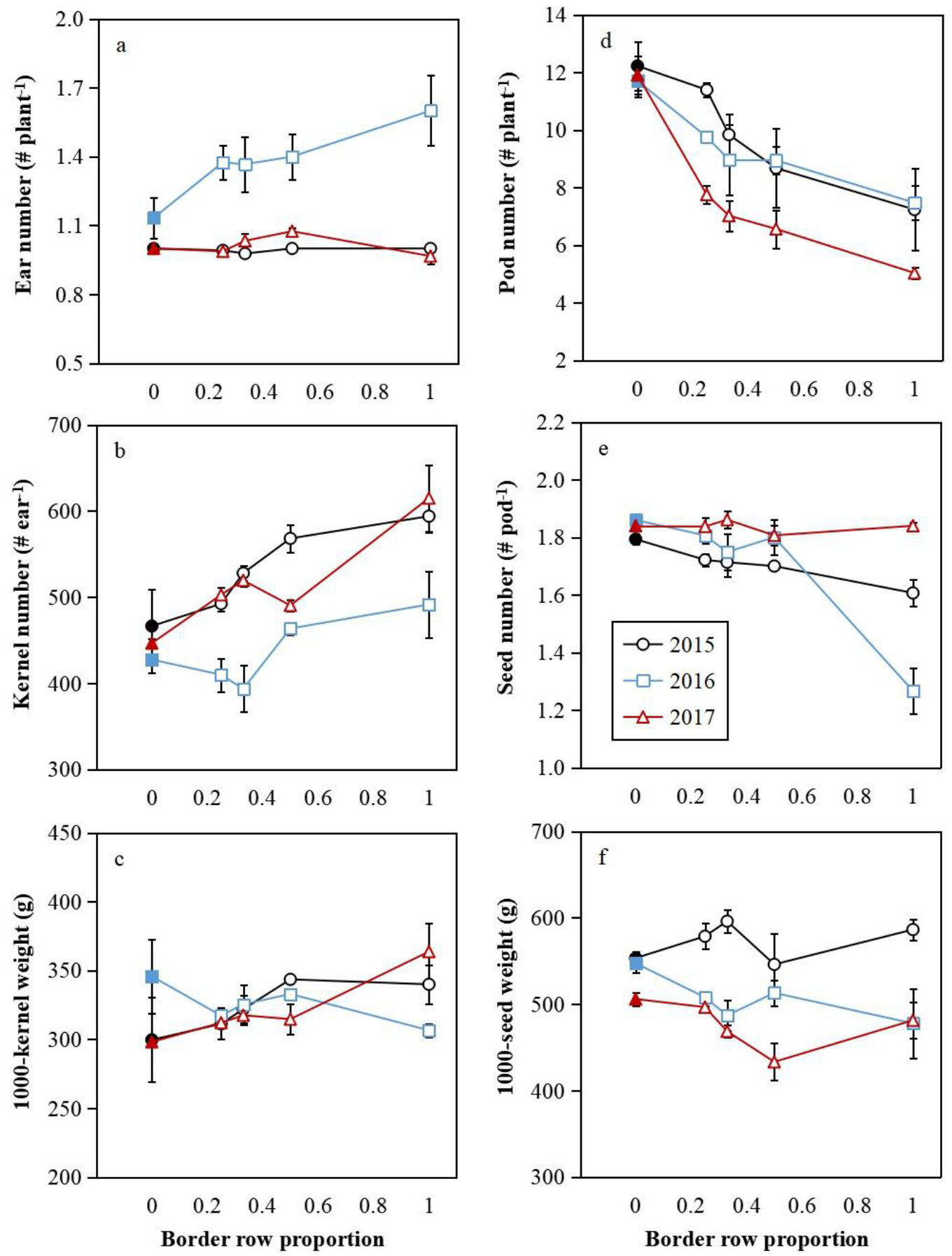

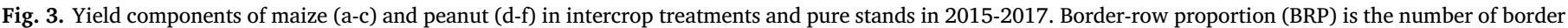

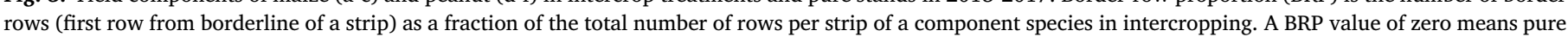

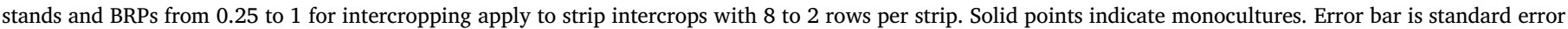
(SE) of the mean based on three replicates.

\section{Discussion}

This study shows how modification of strip width and the associated change in the proportion of border rows have major effects on the relative yields of maize and peanut in strip intercropping. In maize, the relative yield, compared to the pure stand, increased from 0.56 when cultivated in $4 \mathrm{~m}$-wide strips (i.e. M8P8), covering half of the crop area, to 0.76 when grown in narrow $1 \mathrm{~m}$-wide strips (i.e. M2P2), covering the same proportion of the total crop area but using narrower strips of both maize and peanut. In peanut, the relative yield, compared to the pure stand, decreased from 0.39 when cultivated in $4 \mathrm{~m}$-wide strips to 0.19 when cultivated in narrow strips of two rows $(1 \mathrm{~m})$ wide. Therefore, strip width is a powerful way to modify crop yield and species interaction in strip intercropping.

Mixing cereals with legumes has been often reported to improve land productivity as a result of complementarity between $\mathrm{N}$ capture from soil by the cereal and $\mathrm{N}$ fixation from air by the legume (Reddy and Willey, 1981; Kermah et al., 2017). Our results did not show yield increase at system level in any of the configurations. In the maize/ peanut intercropping system used in this study, the yield gain of 

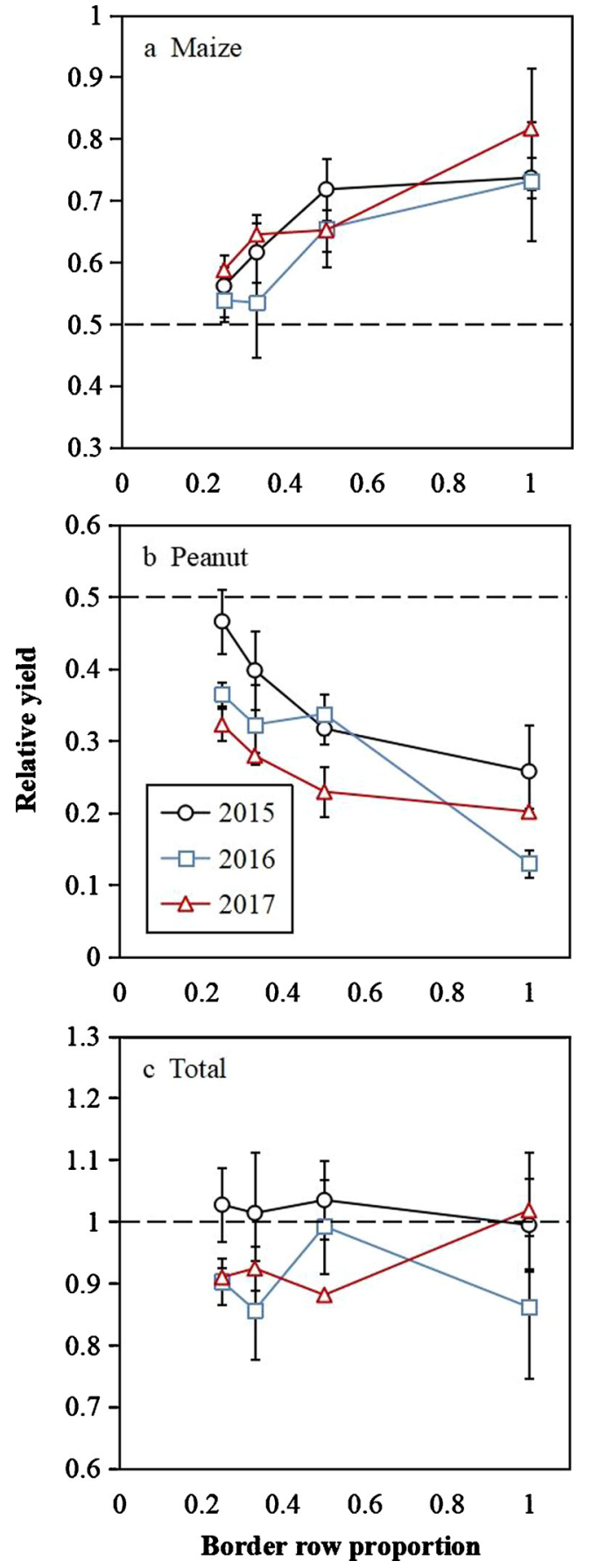

Fig. 4. Relative yields of maize (a), peanut (b) and relative yield total (c) in intercrops with different border-row proportions in 2015-2017. Border-row proportion (BRP) is the number of border rows (first row from borderline of a strip) divided by the total number of rows per strip of a component species in intercropping. BRP values from 0.25 to 1 represent intercrops with different number of rows per strip, from M8P8 (8 rows maize and 8 rows peanut) to M2P2. Error bar is the standard error of the mean (SE) based on three replicates. Dashed line indicates the land use proportion, i.e. the expected relative yield without intercropping effects.

intercropped maize was offset by a yield loss of peanut in all cases. The relative yield total was not changed by strip width due to an apparent lack of complementarity between species, partially caused by the complete temporal overlap of both species, which results in strong competition between the species and limited opportunity for complementary resource capture in time. Also, in semi-arid areas, the advantage of intercropping may be limited by a lack of complementarity for water acquisition (Zhang et al., 2019). Relative yield totals are typically higher than 1 in systems in which the species overlap only partially (relay intercrops) and which are irrigated and thus not limited to the same extent by water availability as our system (Zhu et al. 2015).

Crop species with a lower plant height like peanut experience negative border-row effects, likely due to shading by the border rows of companion crop (tall maize plants) (Liu et al., 2017; Wang et al., 2017b). These negative effects of shading extend some distance into the inner rows of the lower crop species, as found previously in sunflower/ mustard intercropping (Putnam and Allan, 1992) and jujube/cotton agroforestry (Wang et al., 2016). In the shaded crop strip, the rows farthest from the border of the taller crop generally obtain the highest yields (Wang et al., 2017a). Wider strips tend to have less shading effect on inner rows. The peanut yield increased slightly from row 1 to row 4 in the intercropping, presumably due to the alleviation of maize shading. From this point of view, the strip of shaded species could be widened within a certain range. Besides, with a fixed strip width, widening the distance between adjacent maize and peanut but narrowing the row spacing within crop strips might improve the light environment especially for border-row peanuts (Liu et al., 2018). The optimal plant density in intercropping might differ from that in sole cropping. The fundamental mechanism on these issues needs a further study.

In our study, all the inner rows of peanut were affected by maize, however, there was an exception in peanut rows 3 and 4 in M8P8 in 2015. This case was probably due to smaller maize plant sizes as a result of low rainfall in that year. The total rainfall was $41 \%$ lower during the growing season of 2015 than in the other two years, resulting in a significant lower biomass of maize and thus reducing the magnitude of the negative effects on the intercropped peanut.

A change in light condition may induce morphological changes in the plants, e.g. thinner and more erect leaves. Phenotypic plasticity (e.g. specific leaf area and leaf angle) of the shaded crop could partially alleviate the reduction of light interception and increase radiation use efficiency (Zhu et al., 2015; Abakumova et al., 2016; Gou et al., 2017). In agroforestry, increasing crop density can sometimes help to mitigate yield losses resulting from shading (Zhang et al., 2014; Wang et al., 2016). However, it might cause an increase in intraspecific competition.

Yield loss in peanut is associated with an increased plant height in response to shading (Egara and Jones, 1977; Rylski and Spigelman, 1986). In peanut, the flowering is above-ground, but the peanut grows belowground, after the young fruit, called peg, bores into the ground. This boring into the ground (called "pegging") is possibly affected when plants are etiolated due to lack of radiation as a result of shading by tall plants in an intercrop. There is little information on the morphological responses of peanut to shading by maize and it is not known whether such responses, if they exist, are functional in the sense that they help alleviate the shading effects of maize and improve the performance of peanut. The contrary may be the case, e.g. if etiolated plants have reduced pegging efficiency. Further work is needed to characterize the plastic plant responses of peanut in maize/peanut intercropping, and determine whether they alleviate the negative effects of shading on peanut yield. The yield of intercropped peanut might be enhanced by applying ridge-furrow cultivation (Dong et al., 2017) to improve 'peg' penetration into the soil and subsequent peg elongation, thus increasing pod number.

Sowing the subordinate species earlier than the dominant species would be another option to alleviate light competition. (In the study region, climate restrictions allow the cultivation of only one crop per year and do not allow growing one crop earlier than another crop in maize/peanut intercropping). Sole cropping of peanut causes wind erosion as harvesting requires uprooting of the crop, which results in loosening of the soil. Maize as another popular crop in this region requires more water than peanut, thus, often faces drought stress because 


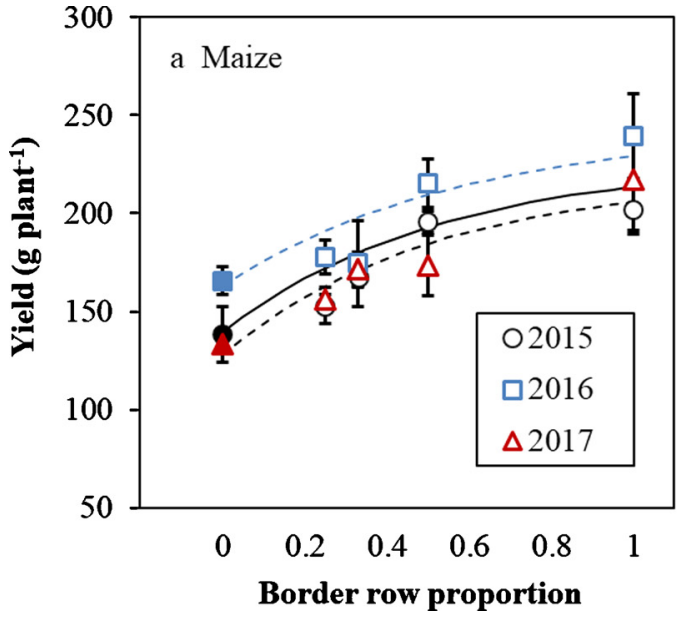

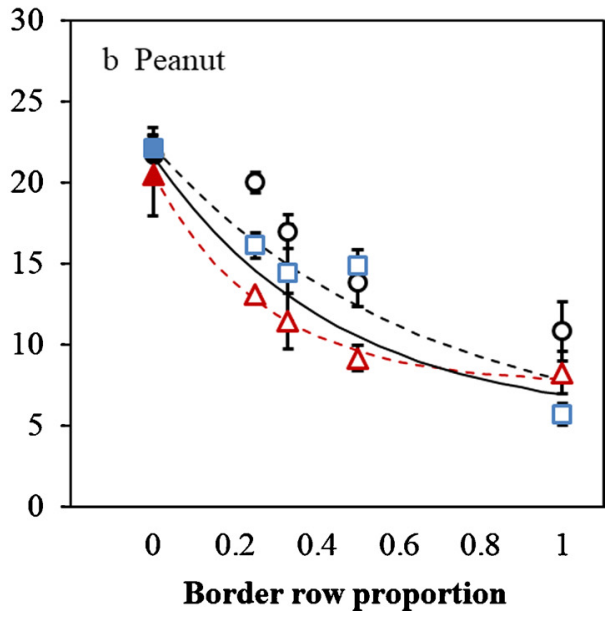

Fig. 5. Maize and peanut yield response to border-row proportion in 2015-2017. Solid points indicate monocultures. Yields per plant are averaged over the whole plot. Border-row proportion (BRP) is the number of border rows (first row from borderline of a strip) divided by the total number of rows in a strip of a component species in intercropping. A BRP value of 0 means a pure stand while values from 0.25 to 1 indicate intercrops from M8P8 (8 rows maize and 8 rows peanut) to M2P2. Error bar is standard error of the mean (SE). Blue and red dashed lines are for maize in 2016 and for peanut in 2017. The black dashed lines are common fitted lines for maize in 2015 and 2017, and for peanut in 2015 and 2016. Common lines for data of 2 years were fitted if there were no significant differences in parameters between the individual years. Solid black lines are the average for each crop in 2015-2017. of insufficient rainfall and high annual variation. Although without yield advantage of the intercropping in this study, intercropping peanut and maize could mitigate wind erosion by leaving maize stubble over the winter and alleviate drought stress due to the complementarity of water use especially in dry years.

Conventional intercropping of maize and peanut (without temporal niche differentiation) could be beneficial due to complementarity for use of both water and nutrient resources. Interspecific interactions between legumes and cereals increase nitrogen acquisition of cereals, which increases nitrogen fixation of legumes (Li et al., 2013). Likewise, if there is iron deficiency in the soil, the presence of maize has a facilitative effect on the peanut because siderophores from maize bring $\mathrm{Fe}$ in solution, supporting iron uptake by the peanut (Zuo et al., 2000). However, such condition did not occur in our experiment.

\section{Conclusions}

Overall, the dominant maize benefited from increasing border-row proportion while peanut suffered from that. Wide strips in intercropping are convenient for mechanization, but widening strip reduces positive border-row effects on a field scale. The optimization of row configuration in maize/peanut intercropping is still a challenge for future studies. The key points are to alleviate negative effects of intercropping on peanut and amplify positive border-row effects of maize. In practice, a combination with narrow maize and wide peanut strips, e.g. 2 rows maize and 4 rows peanut, would be a reasonable choice. A narrow maize strip ( 2 rows) can magnify positive border effects because all rows are the border rows, which intercepts more light by both sides of a strip, and resulting an increase of photosynthesis at low canopy layer. A wide peanut strip reduces the border-row proportion of peanut, which minimizes negative border-row effects of peanut caused by the shading. The $2 \mathrm{~m}$ width of peanut strip in the intercropping with 2 rows maize and 4 rows peanut allows machine operations by a small tractor specially designed for intercropping in China. Our results are useful to understand the interspecific interactions in mixture cropping systems. This knowledge contributes to an optimization of the row configuration in intercropping and the potential of strip cropping for sustainable intensification.

\section{Author statement}

All authors approve the submitted manuscript.

Ruonan Wang did the experiment and wrote the manuscript. Zhangxiang Sun, Lizhen Zhang, Jochem B. Evers and Wopke van der Werf designed the experiment and developed scientific questions and objectives. Lizhen, Jochem and Wopke did the revising. Ning Yang, Liangshan Feng and Wei Bai helped experiment design, management and provided data analyses in relation to local conditions. Dongsheng Zhang, Qi Wang, Yang Liu, Jianhong Ren and Yue Zhang did the experiment and data analyses together with the first author. All authors contributed to the discussion of developing the manuscript by providing comments.

\section{Declaration of Competing Interest}

There are no any conflicts of interest.

\section{Acknowledgements}

The research was supported by the International Cooperation and Exchange of the National Science Foundation of China (31461143025) and National Key Research and Development Program of China

Table 4

Fitted parameters of exponential regressions for plant yields in response to border-row proportion of maize and peanut in intercropping in $2015-2017$.

\begin{tabular}{|c|c|c|c|c|c|c|c|c|c|c|}
\hline \multirow[t]{2}{*}{ Year } & \multicolumn{5}{|l|}{ Maize } & \multicolumn{5}{|l|}{ Peanut } \\
\hline & $\mathrm{a}$ & $\mathrm{b}$ & $\mathrm{k}$ & $\mathrm{RMSE}^{\mathrm{a}}$ & nRMSE & $\mathrm{a}$ & $\mathrm{b}$ & $\mathrm{k}$ & RMSE & nRMSE \\
\hline 2015 & 218.A & $122 \mathrm{~B}$ & $2.21 \mathrm{~A}$ & 6.83 & $4.1 \%$ & $22.5 \mathrm{~A}$ & $5.48 \mathrm{~A}$ & $1.26 \mathrm{~B}$ & 1.48 & $9.1 \%$ \\
\hline 2016 & $244 \mathrm{~A}$ & $163 \mathrm{~A}$ & $1.71 \mathrm{~A}$ & 11.17 & $5.6 \%$ & $22.0 \mathrm{~A}$ & $2.55 \mathrm{~A}$ & $1.86 \mathrm{~B}$ & 1.90 & $13.9 \%$ \\
\hline 2017 & $219 \mathrm{~A}$ & $133 \mathrm{~B}$ & $1.74 \mathrm{~A}$ & 5.06 & $3.0 \%$ & $20.5 \mathrm{~A}$ & $7.53 \mathrm{~A}$ & $3.66 \mathrm{~A}$ & 0.31 & $2.5 \%$ \\
\hline Total $^{\mathrm{b}}$ & 227 & 139 & 1.89 & 16.95 & $9.4 \%$ & 21.6 & 5.19 & 2.26 & 2.46 & $17.4 \%$ \\
\hline SE & 22.8 & 19.4 & 0.429 & - & - & 1.97 & 3.128 & 1.230 & - & - \\
\hline
\end{tabular}

Same capital letter indicates no significant difference between years at $a=0.05$.

The parameter $a$ indicates the maximum yield, $b$ is minimum yield and $k$ is the "rate coefficient" in the exponential regressions (Eqs. 2 \& 3 ).

a RMSE is root mean square error and nRMSE is the normalized RMSE.

b Total indicates the average parameters of the three years. 

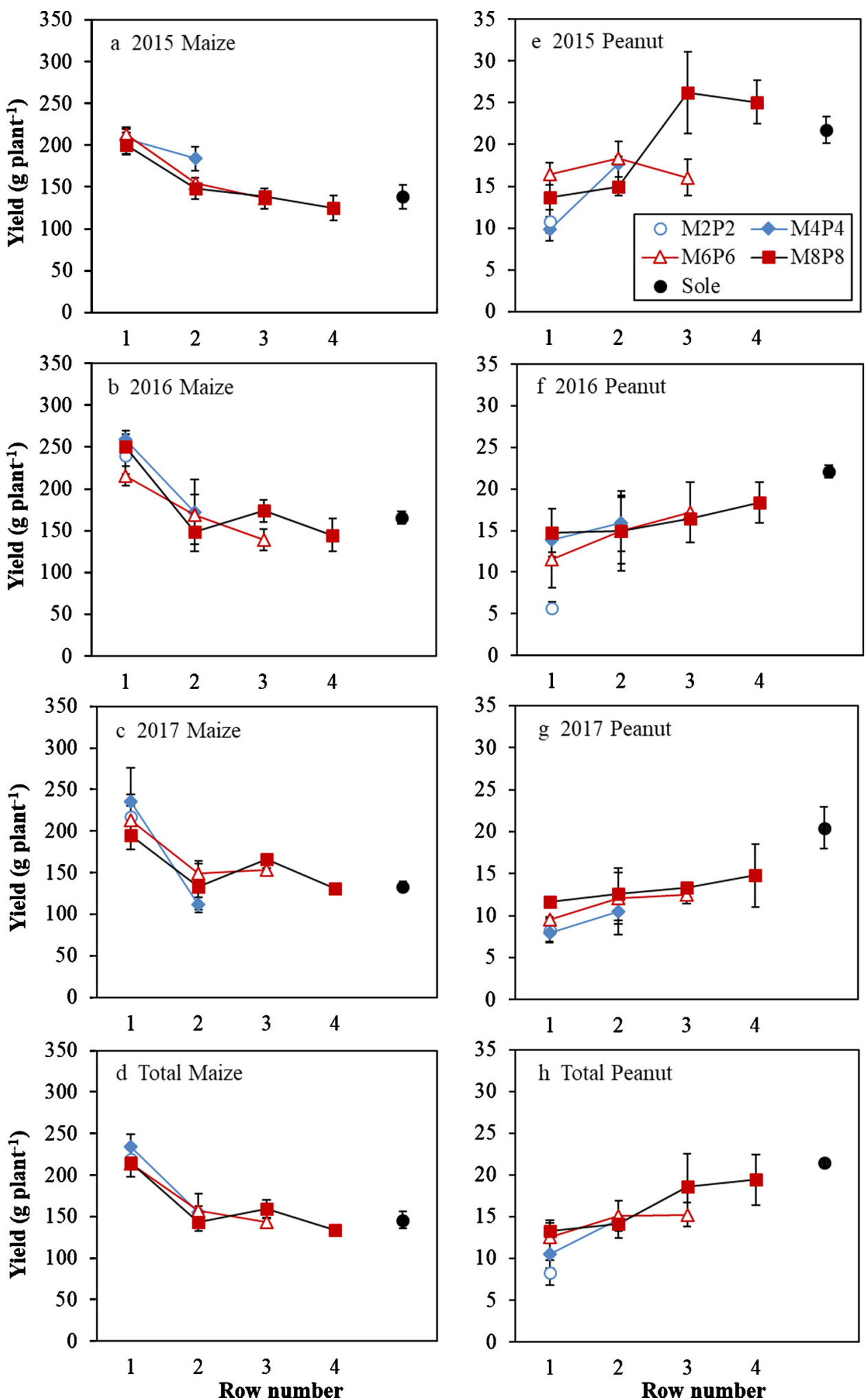

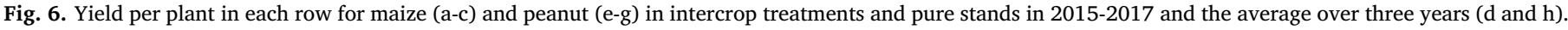

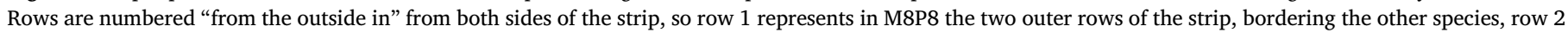
represents the next two rows, etc. Error bars represent standard error of the mean (SE).

(2016YFD0300202). The work was partly supported by the European Union through the project H2020 ReMIX (Redesigning European cropping systems based on species mixtures, https://www.remixintercrops.eu/) number 727217.

\section{Appendix A. Supplementary data}

Supplementary material related to this article can be found, in the online version, at doi:https://doi.org/10.1016/j.fcr.2020.107819. 


\section{References}

Abakumova, M., Zobel, K., Lepik, A., Semchenko, M., 2016. Plasticity in plant functional traits is shaped by variability in neighbourhood species composition. New Phytol. 211, 455-463.

Boudreau, M.A., 2013. Diseases in intercropping systems. Annu. Rev. Phytopathol. 51, 499-519.

Bravo, O., Silenzi, J.C., 2002. Strip cropping in the semi-arid region of Argentina: control of wind erosion and soil water accumulation. Soil Sci. 167, 346-352.

Chen, Z., Cui, H., Wu, P., Zhao, Y., Sun, Y., 2010. Study on the optimal intercropping width to control wind erosion in north china. Soil Till. Res. 110, 230-235.

Cong, W.F., Hoffland, E., Li, L., Six, J., Sun, J.H., Bao, X.G., Zhang, F.S., van der Werf, W., 2015. Intercropping enhances soil carbon and nitrogen. Global Change Biol. 21, $1715-1726$.

Dong, W., Zhang, L., Duan, Y., Sun, L., Zhao, P., van der Werf, W., Evers, J.B., Wang, Q., Wang, R., Sun, Z., 2017. Ridge and furrow systems with film cover increase maize yields and mitigate climate risks of cold and drought stress in continental climates. Field Crops Res. 207, 71-78.

Egara, K., Jones, R.J., 1977. Effect of shading on the seedling growth of the leguminous shrub leucaena leucocephala. Aust. J. Exp. Agr. 17.

Francis, C., Jones, A., Crookston, K., Wittler, K., Goodman, S., 1986. Strip cropping corn and grain legumes: a review. Am. J. Alternative Agr. 1, 159-164.

Gou, F., van Ittersum, M.K., Simon, E., Leffelaar, P.A., van der Putten, P.E.L., Zhang, L., van der Werf, W., 2017. Intercropping wheat and maize increases total radiation interception and wheat RUE but lowers maize RUE. Eur. J. Agron. 84, 125-139.

Kermah, M., Franke, A.C., Adjei-Nsiah, S., Ahiabor, B.D.K., Abaidoo, R.C., Giller, K.E., 2017. Maize-grain legume intercropping for enhanced resource use efficiency and crop productivity in the Guinea savanna of northern Ghana. Field Crops Res. 213, 38-50.

Li, L., Yang, S., Li, X., Zhang, F., Christie, P., 1999. Interspecific complementary and competitive interactions between intercropped maize and fababean. Plant Soil 212, 105-114.

Li, L., Zhang, L., Zhang, F., 2013. Crop mixtures and the mechanisms of overyielding. In: Levin, S.A. (Ed.), Encyclopedia of Biodiversity, second edition, pp. 382-395.

Lithourgidis, A.S., Dordas, C.A., Damalas, C.A., Vlachostergios, D.N., 2011. Annual intercrops: an alternative pathway for sustainable agriculture. Aust. J. Crop Sci. 5, 396-410.

Liu, X., Rahman, T., Song, C., Su, B., Yang, W., 2017. Changes in light environment, morphology, growth and yield of soybean in maize-soybean intercropping systems. Field Crops Res. 200, 38-46.

Liu, X., Rahman, T., Song, C., Yang, F., Su, B., Cui, L., Bu, W., Yang, W., 2018. Relationships among light distribution, radiation use efficiency and land equivalent ratio in maize-soybean strip intercropping. Field Crops Res. 224, 91-101.

Ma, K.Z., Hao, S.G., Zhao, H.Y., Kang, L., 2007. Strip cropping wheat and alfalfa to improve the biological control of the wheat aphid macrosiphum avenae by the mite allothrombium ovatum. Agric. Ecosyst. Environ. 119, 49-52.

Mead, R., Willey, R.W., 1980. The concept of a land equivalent ratio and advantages in yields for intercropping. Expl. Agric. 16, 217-228.

Morris, R.A., Garrity, D.P., 1993. Resource capture and utilization in intercropping: water. Field Crops Res. 34, 303-317.

Peel, M.C., Finlayson, B.L., McMahon, T.A., 2007. Updated world map of the Köppen
Geiger climate classification. Hydrol. Earth Syst. Sci. 11, 1633-1644.

Putnam, D.H., Allan, D.L., 1992. Mechanisms for overyielding in a sunflower/mustard intercrop. Agron. J. 84, 188-195.

Raseduzzaman, Md., Jensen, E.S., 2017. Does intercropping enhance yield stability in arable crop production? A meta-analysis. Eur. J. Agron. 91, 25-33.

Reddy, M.S., Willey, R.W., 1981. Growth and resource use studies in an intercrop of pearl millet/groundnut. Field Crops Res. 4, 13-24.

Rylski, I., Spigelman, M., 1986. Effect of shading on plant development, yield and fruit quality of sweet pepper grown under conditions of high temperature and radiation. Sci. Hortic. 29, 31-35.

Trenbath, B.R., 1993. Intercropping for the management of pests and diseases. Field Crops Res. 34, 381-405.

Vandermeer, J., 1989. The ecology of intercropping. Cambridge University Press, Cambridge.

van Oort, P., Gou, F., Stomph, T.J., van der Werf, W., 2020. Effects of strip width on yields in relay-strip intercropping: a simulation study. Eur. J. Agron. 112, 125936. https:// doi.org/10.1016/j.eja.2019.125936.

Wang, Q., Han, S., Zhang, L., Zhang, D., van der Werf, W., Evers, J.B., Sun, H., Su, Z., Zhang, S., 2016. Density responses and spatial distribution of cotton yield and yield components in jujube (Zizyphus jujuba)/cotton (Gossypium hirsutum) agroforestry. Eur. J. Agron. 79, 58-65.

Wang, Q., Zhang, D., Zhang, L., Han, S., van der Werf, W., Evers, J.B., Su, Z., Anten, N.P.R., 2017a. Spatial configuration drives complementary capture of light of the understory cotton in young jujube plantations. Field Crops Res. 213, 21-28.

Wang, Z., Zhao, X., Wu, P., Gao, Y., Yang, Q., Shen, Y., 2017b. Border-row effects on light interception in wheat/maize strip intercropping systems. Field Crops Res. 214, 1-13.

Willey, R.W., Rao, M.R., 1980. A competitive ratio for quantifying competition between intercrops. Expl. Agric. 16, 117-125.

Yu, Y., Stomph, T.J., Makowski, D., van der Werf, W., 2015. Temporal niche differentiation increases the land equivalent ratio of annual intercrops: A meta-analysis. Field Crops Res. 184, 133-144.

Yu, Y., Stomph, T.J., Makowski, D., Zhang, L., van der Werf, W., 2016. A meta-analysis of relative crop yields in cereal/legume mixtures suggests options for management. Field Crops Res. 198, 269-279.

Zhang, C., Dong, Y., Tang, L., Zheng, Y., Makowski, D., Yu, Y., Zhang, F., van der Werf, W., 2019. Intercropping cereals with faba bean reduces plant disease incidence regardless of fertilizer input: a meta-analysis. Eur. J. Plant Pathol. 154, 931-942.

Zhang, D., Zhang, L., Liu, J., Han, S., Wang, Q., Evers, J.B., Liu, J., van der Werf, W., Li, L., 2014. Plant density affects light interception and yield in cotton grown as companion crop in young jujube plantations. Field Crops Res. 169, 132-139.

Zhang, F., Li, L., 2003. Using competitive and facilitative interactions in intercropping systems enhances crop productivity and nutrient-use efficiency. Plant Soil 248, 305-312.

Zhang, L., van der Werf, W., Zhang, S., Li, B., Spiertz, J., 2007. Growth: yield and quality of wheat and cotton in relay strip intercropping systems. Field Crops Res. 103, $178-188$.

Zhu, J., van der Werf, W., Anten, N.P.R., Vos, J., Evers, J.B., 2015. The contribution of phenotypic plasticity to complementary light capture in plant mixtures. New Phytol. 207, 1213-1222.

Zuo, Y., Zhang, F., Li, X., Cao, Y., 2000. Studies on the improvement in iron nutrition of peanut by intercropping with maize on a calcareous soil. Plant Soil 220, 13-25. 